\title{
PERBEDAAN HASIL BELAJAR SISWA YANG DIAJAR MENGGUNAKAN MODEL PEMBELAJARAN PROBLEM BASED LEARNING DENGAN PROBLEM BASED LEARNING PADA MATERI PENCEMARAN DAN KERUSAKAN LIGKUNGAN DI KELASVII SMP NEGERI 1 SEI BINGAI KABUPATEN LANGKAT
}

\author{
DIFFERENCES OF STUDENTS LEARNING OUTCOMES TAUGHT USING PROBLEM BASED LEARNING MODEL \\ WITH PROJECT BASED LEARNING IN POLLUTION AND ENVIRONMENTAL DAMAGE MATERIALS FOR GRADE VII \\ AT SMP NEGERI 1 SEI BINGAI
}

\author{
Dwi Aryuli Br Sitepu ${ }^{*}$ dan Masdiana Sinambela \\ Program Studi Pendidikan Biologi, FMIPA, Universitas Negeri Medan, Jl. Willem Iskandar Psr. V Medan Estate \\ Fax. (061) 614002-613319, Medan, Indonesia, 20221 \\ *E-mail : dwiaryulie94@gmail.com
}

\begin{abstract}
Abstrak
Penelitian ini bertujuan untuk mengetahui perbedaan hasil belajar siswa menggunakan Model Pembelajaran Problem Based Learning dengan Model Pembelajaran Project Based Learning pada materi Pencemaran dan Kerusakan Lingkungan di kelas VII SMP Negeri 1 Sei Bingai T.P 2015/2016 yang terdiri dari 7 kelas dengan jumlah siswa 224 orang. Sedangkan sampel diambil berdasarkan random sampling sebanyak dua kelas yaitu 64 siswa, yaitu 32 siswa kelas VII-1 (menggunakan Model Pembelajaran Problem Based Learning) dan 32 orang kelas VII-2 (menggunakan Model Pembelajaran Project Based Learning). Jenis penelitian yang dilakukan adalah eksperimental. Pada kelas eksperimen I (menggunakan Model Pembelajaran Problem Based Learning ) didapat rata-rata hasil belajar siswa sebesar 82,71 dengan standar deviasi 4,75 sedangkan pada kelas eksperimen II (menggunakan Model Pembelajaran Project Based Learning) memiliki rata-rata sebesar 90,63 dengan standar deviasi 5,32. Adanya perbedaan hasil belajar tersebut dibuktikan melalui pengujian hipotesis dengan menggunakan uji-t pada taraf $\alpha=0,05$, dimana $t_{\text {hitung }}(-14,14)<t_{\text {tabel }}(-1,667)$. Hipotesis menggunakan uji t menunjukkan bahwa hasil tersebut berbeda secara signifikan pada taraf kepercayaan $\alpha=0,05$.
\end{abstract}

Kata Kunci: Hasil Belajar Siswa, Problem Based Learning, Project Based Learning.

\begin{abstract}
This study aims to determine the differences of student learning outcomes using Problem Based Learning Model with Model Project Based Learning on the material Pollution and Environmental Degradation in class VII SMP Negeri 1 Sei Bingai T.P 2015/2016 consists of 7 classes with 224 students enrolled. While samples taken by random sampling as much as two classes of 64 students; 32 students of class VII-1 (using Problem Based Learning Model Learning) and 32 classes VII-2 (using Project Based Learning Model). Type of research is experimental. In the experimental class I (using Problem Based Learning Model) obtained an average student learning outcomes at 82.71 with a standard deviation of 4.75 , while the experimental class II (using the Model Learning Project Based Learning) has an average of 90.63 with a standard deviation of 5.32. The big difference in learning outcomes is proved by testing the hypothesis by using t-test at the level of $\alpha=0.05$, which were encountered (14.14)> $t$ table (1.6697). Hypothesis test used $t$ test showed that the result was significantly different at the level of confidence $\alpha=0,05$.
\end{abstract}

Keywords: Hasil belajar siswa, Problem Based Learning, Project Based Learning.

\section{PENDAHULUAN}

Pada umumnya pendidikan dilakukan melalui proses pembelajaran. Pembelajaran merupakan proses interaksi siswa dengan lingkungannya sehingga terjadi perubahan prilaku ke arah yang lebih baik. Pembelajaran diharapkan dapat mengembangkan semua aspek dan potensi yang ada pada siswa, baik aspek kognitif, efektif, maupun psikimotoriknya, sehingga PBM tidak lagi berpusat pada guru saja, namum memberi kesempatan pada siswa untuk melakukan berbagai kegiatan belajar. Namun, pada kenyataannya masih banyak guru yang dalam proses pembelajaran, siswa kurang didorong untuk 
mengembangkan kemampuan berpikir. Proses pembelajaran di dalam kelas hanya diarahkan pada kemampuan siswa untuk menghapal informasi dan dipaksa untuk mengingat dan menimbun berbagai informasi tanpa memahami informasi yang diingatnya (Jihad et al, 2013).

Berdasarkan hasil observasi yang dilakukan dan hasil diskusi dengan salah seorang guru IPA di SMP Negeri 1 Sei Bingai, satu kesulitan yang sering dihadapi oleh guru adalah memilih model pembelajaran yang paling tepat dalam menyampaikan materi pembelajaran. Sehingga, banyak siswa yang tidak aktif di kelas dalam proses belajar mengajar. Hal ini menyebabkan $40 \%$ siswa belum mencapai kriteria ketuntasan minimal dan 60\% siswa yang mencapai kriteria ketuntasan minimal. Kriteria ketuntaan minimal pada pelajaran IPA di kelas VII adalah 70 .

Pada materi pelajaran pencemaran dan kerusakan lingkungan, tujuan dari pelajaran tersebut adalah mengharapkan siswa agar mampu mengaplikasikan ilmu yang didapat dan mampu memecahkan masalah serta memberikan solusisolusi handal dalam memecahkan masalah lingkungan. Alangkah baiknya jika materi tersebut diajarkan dengan model pembelajaran yang bisa mengarahkan siswa agar mampu mengaplikasikan dari ilmu pengetahuan yang diterimanya di sekolah.

Untuk mengantisipasi hal tersebut, maka perlu dicarikan formula pembelajaran yang tepat, yang berorientasi student-centered atau pembelajaran yang berpusat pada siswa. Salah satu model pembelajaan yang berorientasikan student-centered adalah model pembelajaran berdasarkan masalah (Problem based learning) dan salah satu model pembelajaran yang mendorong siswa untuk menghasilkan karya proyek yang nyata adalah model pembelajaran berbasis proyek (Project based learning). Problem based learning (PBL) merupakan salah satu model pembelajaran yang menggunakan masalah dunia nyata sebagai konteks bagi perserta didik untuk belajar tentang cara berfikir kritis dan keterampilan pemecahan masalah, serta untuk memperoleh pengetahuan dan konsep yang esensial dari meteri pelajaran. Pembelajaran berbasis proyek (Project based learning) merupakan model pembelajaran yang melibatkan siswa secara aktif dalam merancang tujuan pembelajaran untuk menghasilkan produk atau proyek yang nyata (Sutirman, 2013).

Menurut Astuti (2013), penerapan model pembelajaran berbasis masalah (Problem based learning) dapat meningkatkan hasil belajar siswa, pada siklus I siswa yang tuntas sebanyak 19 siswa dari 30 siswa atau $63,3 \%$, sedangkan siswa yang tidak tuntas sebanyak 11 siswa dari 30 siswa atau $26,7 \%$. Dan pada sisklus II, siswa yang tuntas sebanyak 25 siswa dari 30 siswa atau $83,3 \%$.

Menurut Susilowati (2013), model pembelajaran berbasis proyek berpengaruh terhadap hasil belajar siswa, hasil rata-rata nilai post-test kelas eksperimen lebih baik dibanding dengan kelas kontrol. Selain itu, rata-rata nilai akhir siswa kelas eksperimen lebih tinggi dari pada kelas kontrol yakni pada kelas eksperimen sebesar 83 dan ketuntsan belajarnya mencapai 100\% sedangkan pada kelas kontrol rata-rata nilai akhirnya sebesar 76 dan katuntasan belajarnya hanya $89,7 \%$.

Berdasarkan uraian di atas maka penulis merasa perlu untuk melakukan penelitian tentang Perbedaan Hasil Belajar Siswa yang Diajar Menggunakan Model Pembelajaran Problem Based Learning dengan Project Based Learning pada Materi Pencemaran dan Kerusakan Lingkungan di Kelas VII SMP Negeri 1 Sei Bingai Tahun Pembelajaran 2015/2016. Penggunaan model pembelajaran Problem Based Learning dan Project Based Learning diharapkan dapat mengaktifkan siswa dalam proses pembelajaran biologi, meningkatkan pemahaman siswa dalam materi sistem pencemaran dan kerusakan lingkungan sehingga mampu mengaktifkan siswa dalam proses pembelajaran dan dapat meningkatkan hasil belajar biologi. Penelitian ini bertujuan untuk mengetahui ada tidaknya perbedaan hasil belajar biologi siswa yang diajar menggunakan model pembelajaran Problem Based Learning dan Project Based Learning pada materi pencemaran dan kerusakan lingkungan di kelas VII SMP Negeri 1 Sei Bingai tahun pembelajaran 2015/2016. 


\section{METODE PENELITIAN}

Lokasi Penelitian ini dilaksanakan di SMP Negeri 1 Sei Bingai Kabupaten Langkat yang terletak di Jalan Pendidikan No.5 Namu Ukur Selatan dan waktu penelitian pada bulan April-Juni 2016. Populasi penelitian adalah seluruh siswa kelas VII SMP Negeri 1 Sei Bingai Kabupaten Langkat yang terdiri dari tujuh kelas, dengan jumlah 224 siswa. Sampel penelitian ini diambil sebanyak 2 kelas VII SMP Negeri 1 Sei Bingai Kabupaten Langkat. Dimana teknik pengambilan sampel dengan cara random sampling yaitu kelas Eksperimen I diajar menggunakan model pembelajaran Problem Based Learning dengan jumlah siswa sebanyak 32 siswa dan kelas eksperimen II diajar menggunakan model pembelajaran Project Based Learning dengan jumlah siswa 32 siswa. Jadi total sampel sebanyak 64 orang siswa.

Jenis penelitian ini adalah penelitian eksperimen semu. Jenis data yang digunakan adalah jenis data kuantitatif, yaitu data tentang hasil belajar siswa didapatkan dari hasil pengisian tes akhir (postes). Tes akhir penelitian memuat pertanyaan-pertanyaan yang berkaitan dengan materi yang telah diajarkan. Tes yang diberikan adalah tes tertutup yaitu kemungkinan jawaban sudah ditentukan terlebih dahulu dan responden tidak diberi kesempatan untuk memberikan jawaban lain. Angket analisis faktor kesulitan belajar ini diberikan dengan tipe pilihan ganda. Tes hasil belajar terdiri dari 20 item yang disusun dengan bentuk pilihan berganda. Tes ini diberikan kepada siswa dan siswa tinggal memilih dari empat option pilihan jawaban yang telah disediakan. Soal yang dijawab benar diberi skor 1 dan jika salah diberi skor 0 . Untuk melihat kelayakan instrumen penelitian dilakukan uji kelayakan data berupa uji validitas tes, uji reliabilitas tes, uji indeks (tingkat) kesukaran soal, dan uji daya beda (indeks diskriminan) tes.

\section{HASIL PENELITIAN}

Berdasarkan hasil penelitian diperoleh bahwa nilai rata-rata hasil belajar siswa pada kelas Problem Based Learning sebesar 82,71 dengan simpangan baku (SD) sebesar 4,75 (Lampiran 10). Nilai tertinggi pada kelas Problem Based Learning sebesar 93 sebanyak 1 orang (3,13\%), nilai terendah sebesar 70 sebanyak 1 orang $(3,13 \%)$, dan nilai dengan frekuensi tertinggi yaitu 83 sebanyak 11 orang (34,38\%). Persentasi pencapaian hasil yang diperoleh oleh kelas Problem Based Learning adalah 100\% artinya seluru siswa pada kelas Problem Based Learning memperoleh nilai diatas nilai (Kriteria Ketuntasan Minimal) KKM sekolah.

Tabel 1. Perbedaan Hasil Belajar Siswa di Kelas Problem Based Learning dan Project Based Learning

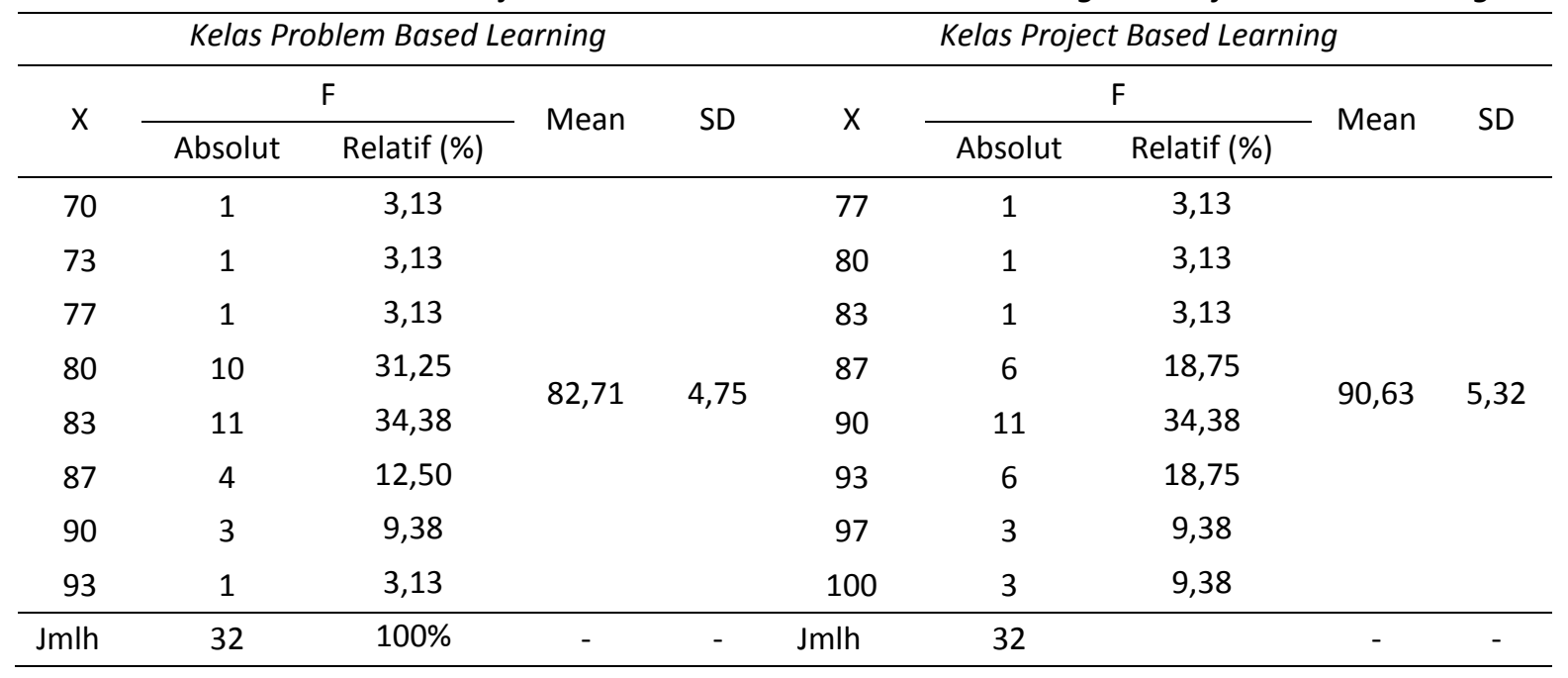


Pada kelas Project Based Learning diperoleh nilai rata-rata hasil belajar siswa sebesar 90,63 dengan simpangan baku (SD) sebesar 5,32 (Lampiran 10). Nilai tertinggi pada kelas Project Based Learning yaitu 100 sebanyak 3 orang $(9,38 \%)$, nilai terendah sebesar 77 sebanyak 1 orang $(3,13 \%)$ dan nilai dengan frekuensi tertinggi sebesar 90 sebanyak 11 orang (34,38\%). Persentasi pencapaian hasil yang diperoleh oleh kelas Project Based Learning adalah $100 \%$ artinya seluruh siswa pada kelas Project Based Learning memperoleh nilai di atas nilai (Kriteria Ketuntasan Minimal) KKM sekolah.

Uji normalitas data tes akhir kelas yang menggunakan model pembelajaran Problem Based Learning diperoleh $L_{\text {hitung }}(-0,012)<\mathrm{L}$ tabel $(0,1568)$ dan data tes akhir kelas yang menggunakan model pembelajaran Project Based Learning diperoleh $L_{\text {hitung }}(-0,01735)<L_{\text {tabel }}(0,1568)$ pada taraf nyata $\alpha=0,05$. Dengan demikian dapat disimpulkan bahwa data pada kelompok sampel berdistribusi normal. Hasil perhitungan uji homogenitas untuk data tes akhir diuji kesamaan variansnya dan diperoleh $F_{\text {hitung }}=1,254$ sedangkan $F_{\text {tabel }}=1,832$, sehingga diperoleh $F_{\text {hitung }}(1,254)<F_{\text {tabel }}(1,832)$ yang berarti data tes awal memiliki varians yang homogen.

Tabel 2. Pengujian Normalitas Data Penelitian

\begin{tabular}{cclccc}
\hline No & Data & \multicolumn{1}{c}{ Kelas } & $\mathbf{L}_{\text {hitung }}$ & $\mathbf{L}_{\text {tabel }}$ & Kesimpulan \\
\hline 1 & Postes & $\begin{array}{l}\text { Kelas Eksperimen I (Problem Based } \\
\text { Learning) }\end{array}$ & $-0,012$ & 0,1568 & Normal \\
2 & Postes & $\begin{array}{l}\text { Kelas Eksperimen II Project Based } \\
\text { Learning }\end{array}$ & $-0,01735$ & 0,1568 & Normal \\
\hline
\end{tabular}

Tabel 3. Pengujian Data Homogenitas

\begin{tabular}{|c|c|c|c|c|c|c|}
\hline Kelas & Data & Varians & $F_{\text {hitung }}$ & $\mathbf{F}_{\text {tabel }}$ & A & Keterangan \\
\hline $\begin{array}{l}\text { Eksperimen I (Problem Based } \\
\text { Learning) }\end{array}$ & Postes & 22,54 & \multirow{2}{*}{1,254} & \multirow{2}{*}{1,832} & \multirow{2}{*}{0,05} & \multirow{2}{*}{ Homogen } \\
\hline $\begin{array}{l}\text { Eksperimen II Project Based } \\
\text { Learning }\end{array}$ & Postes & 28,27 & & & & \\
\hline
\end{tabular}

Berdasarkan tabel hasil perhitungan uji-t, diperoleh $-t_{\text {hitung }}$ sebesar $-14,14$ sedangkan $-t_{\text {tabel }}(d k=62)$ pada taraf $\alpha=0,05$ adalah $-1,67$. Hal ini berarti $-t_{\text {hitung }}$ lebih kecil dari- $t_{\text {tabel }}$ atau $-t_{\text {hitung }}<-t_{\text {tabel }}(-14,14<-1,67)$. Dengan demikian, dapat diinterpretasikan bahwa terdapat perbedaaan yang signifikan hasil belajar biologi siswa kelas VII SMP Negeri 1 Sei Bingai Kabupaten Langkat yang diajar dengan model pembelajaran Problem Based Learning dan Project Based Learning pada materi pencemaran dan kerusakan lingkungan pada taraf kepercayaan $95 \%$.

Tabel 4. Kriteria Pencapaian Kognitif Siswa

\begin{tabular}{cccccc}
\hline \multirow{2}{*}{ Nilai } & \multirow{2}{*}{ Kategori } & \multicolumn{4}{c}{ Frekuensi } \\
\cline { 3 - 5 } & & Problem Based Learning & \multicolumn{2}{c}{ Project Based Learning } \\
\cline { 3 - 5 } & & Absolut & Relatif (\%) & Absolut & Relatif (\%) \\
\hline $90-100$ & Sangat tinggi & 4 & 12,5 & 23 & 71,87 \\
$80-89$ & Tinggi & 26 & 81,25 & 8 & 25 \\
$70-79$ & Sedang & 3 & 9,37 & 1 & 3,13 \\
$60-69$ & Rendah & 0 & 0 & 0 & 0 \\
$\leq 59$ & Sangat Rendah & 0 & 0 & 0 & 0 \\
\hline
\end{tabular}

Tabel 5. Hasil Pengujian Hipotesis Data Posttest Siswa

\begin{tabular}{lcccc}
\hline \multicolumn{1}{c}{ Kelas } & Nilai Rata-rata & $\mathrm{t}_{\text {hitung }}$ & $\mathrm{t}_{\text {tabel }}$ & Kesimpulan \\
\hline Problem Based Learning & 82,71 & $-14,14$ & 1,67 & Ada Perbedaan \\
Project Based Learning & 90,63 & & & \\
\hline
\end{tabular}




\section{PEMBAHASAN}

Berdasarkan deskripsi data hasil penelitian diperoleh prestasi hasil belajar siswa kelas VII SMP Negeri 1 Sei Bingai Kabupaten Langkat, nilai rata-rata hasil belajar siswa yang diperoleh kelas VII-I dengan model pembelajaran Problem Based Learning sebesar 82,71 dengan standart deviasi 4,75 . Nilai tertinggi yang diperoleh siswa adalah 93 sedangkan nilai terendah adalah 70 artinya seluruh siswa pada kelas tersebut mencapai nilai KKM sekolah. . Pada kelas Model pembelajaran Problem Based Learning siswa dibagi dalam beberapa kelompok untuk mengerjakan LKS yang sudah disediakan berupa masalah yang terdapat pada lingkungan, kemudian siswa bekerjasama dengan teman sekelompoknya menyelesaikan masalah dan soal pada LKS. Peneliti mendorong siswa untuk mendapatkan informasi yang tepat untuk mencari menyelesaikan masalah dalam diskusi tersebut. Kemudian perwakilan dari setiap kelompok untuk mempresentasikan hasil diskusi mereka. Dengan menerapkan model pembelajaran Problem Based Learning siswa terdorong untuk mampu memecahkan masalah yang konstektual, mampu mencermati dan mengumpulkan data, menyusun fakta, dan menyusun argumen terkait pemecahan masalah.

Pada kelas VII-II rata-rata hasil belajar siswa dengan model pembelajaran Project Based Learning sebesar 90,63 dengan standart deviasi 5,32. Nilai tertinggi yang diperoleh siswa adalah 100 sedangkan nilai terendah adalah 77 artinya seluruh siswa pada kelas tersebut mencapai nilai KKM sekolah. Pada kelas Model pembelajaran Project Based Learning siswa dibagi dalam beberapa kelompok kemudian peneliti mengajukan pertanyaan untuk melihat tanggapan/ide siswa mengenai tema/proyek dan memberikan LKS, siswa diminta membuat rencana kegiatan dalam menyelesaikan proyek atau masalah serta penyelesaiannya secara berkelompok. Dalam tahap perencanaan peneliti membantu siswa menjawab pertanyaan yang telah diajukan dan mengetahui alat bantu yang dibutuhkan dalam penyelesaian proyek, dan jadwal waktu yang dibuhkan untuk penyelesaian proyek. Pada tahap masalah, peneliti menunjuk perwakilan dari setiap kelompok untuk mempresentasikan hasil proyek mereka. Dengan menepkan model pembelajaran Project Based Learning siswa didorong untuk melakukan kegiatan penyelidikan bersama dengan teman sekelompoknya hingga memungkinkan para siswa dalam tim tersebut mengembangkan keterampilan melakukan riset yang akan bermanfat bagi pengembangan kemampuan akademis mereka.Selain itu siswa didorong untuk memecahkan masalah, mengambil keputusan dan memusatkan diri pada sejumlah masalah yang mampu memotivasi siswa dalam menghadapi permasalahan nyata.

Dari hasil belajar siswa dapat dilihat bahwa model pembelajaran Problem Based Learning dan Project Based Learning sama-sama memberikan kontribusi yang baik pada kedua kelas eksprimen, dimana seluruh siswa pada kedua kelas tersebut memperoleh nilai yang mencapai nilai ketuntasan KKM sekolah. Maka dapat disimpulkan bahwa model pembelajaran Problem Based Learning dan Project Based Learning baik diterapkan pada materi pembelajaran pencemaran dan kerusakan lingkungan.

Dari hasil pengujian hipotesis menggunakan uji $t$, diperoleh $t_{\text {hitung }}$ sebesar $-14,14$ atau $-t_{\text {hitung }}=-14,14$ sedangkan harga $t_{\text {tabel }}=1,67$ atau $-t_{\text {tabel }}=-1,67$ pada taraf signifikansi $\alpha=0,05$ $\mathrm{dan} d \mathrm{k}=62$. Dengan ini diperoleh harga $-t_{\text {hitung }}<-$ $t_{\text {tabel }}$ artinya Ha diterima dan Ho ditolak atau "ada perbedaan yang signifikan antara hasil belajar siswa yang diajar menggunakan Model Pembelajaran Berdasarkan Masalah (Problem Based Learning) dan Model Pembelajaran Berbasis Proyek (Project Based Learning) pada materi pencemaran dan kerusakan lingkungan di kelas VII SMP Negeri 1 Sei Bingai Tahun Pelajaran 2015/2016.

Meskipun kedua model pembelajara diatas yaitu pembelajaran Problem Based Learning dan Project Based Learning berdistribusi baik pada kedua kelas eksperimen, namun berdasarkan analisis data penelitian menunjukkan bahwa hasil belajar siswa yang diajar dengan menggunakan model Prbject Based Learning lebih tinggi dan berbeda secara signifikan dibandingkan 
menggunakan model Project Based Learning. Perbedaan nilai hasil belajar yang diperoleh sebesar 7,92 hal ini dimungkinkan karena tingginya peran aktif siswa dalam kegiatan observasi penyusunan proyek untuk mengumpulkan data yang diperoleh guna merancang proyek dan mengisi lembar LKS. Disamping itu siswa mendapatkan pengalamn pembelajaran dan praktik dalam mengorganisasi proyek dan membuat alokasi waktu dan perlengkapan dalam penyelesaian tugasnya. Pengalaman pembelajaran yang melibatkan siswa pada dunia nyata membuat suasana belajar menjadi menyenangkan sehingga pengetahuan siswa pun berkembang.

Sesuai dengan kondisi pada saat pembelajaran, siswa yang diberi perlakuan dengan model pembelajaran Project Based Learning lebih antusias dalam memahami materi, memberikan pendapat kekelompok, dan bekerjasama dengan teman sekelompoknya untuk menemuka solusi dari masalah yang dibahas dan menerapkannya dalam satu proyek yang nyata. Hal ini diperkuat oleh hasil penelitian Wiyarsi dan Partana (2009), yang menyimpulkan bahwa pembelajaran berbasis proyek efektif dalam meningkatkan aspek kemandirian, apek kerjasama kelompok, dan aspek penguatan psikomotorik. Sama halnya dengan kelas yang diberikan perlakuan dengan model pembelajaan Problem Based Learning, pada saat pembelajaran siswa aktif bekerjasama dengan kelompoknya dalam menyelesaikan masalah yang diberikan. Hal ini sejalan dengan penelitian Siahaan (2010), bahwa model pembelajaran berdasarkan masalah dapat meningkatkan aktivitas dan hasil belajar siswa sub materi pokok ekosistem. Hanya saja beberapa dari siswa pada kelas model pembelajaran Problem Based Learning memiliki minat belajar yang kurang dan kurang antusias dalam mencari informasi untuk memecahkan masalah atau soal yang diberikan sehingga hal ini berdampak pada pemahaman siswa dalam pelajaran dan menyebabkan rendahnya nilai hasil belajar siswa setelah diberikan soal postes.

Dari pembahasan di atas dapat disimpulkan bahwa ada perbedaan yang segnifikan antara hasil belajar siswa yang diberi perlakuan dengan menggunakan model pembelajaran Problem Based Learning dengan Project Based Learning namun kedua model pembelajaran tersebut berkontribusi baik dalam meningkatkan hasil belajar dan ketuntasan belajar siswa.

\section{KESIMPULAN}

Berdasarkan penelitian yang telah dilakukan maka dapat disimpulkan yakni: 1). Hasil belajar siswa menggunakan Model Pembelajaran Problem Based Learning pada materi Perncemaran Dan Kerusakan Lingkungan di kelas VII SMP Negeri 1 Sei Bingai Tahun Pelajaran 2015/2016 adalah 82,71 dengan standar devasi 4,75. 2). Hasil belajar siswa menggunakan Model Pembelajaran Project Based Learning pada materi Perncemaran Dan Kerusakan Lingkungan di kelas VII SMP Negeri 1 Sei Bingai Tahun Pelajaran 2015/2016 adalah 90.63 dengan standar devasi 5,32. 3). Ada perbedaan yang signifikan sebesar 7.92 antara hasil belajar siswa yang diajar menggunakan Model Pembelajaran Berdasarkan Masalah (Problem Based Learning) dengan Model Pembelajaran Berbasis Proyek (Project Based Learning) pada materi pencemaran dan kerusakan lingkungan di kelas VII SMP Negeri 1 Sei Bingai Tahun Pelajaran 2015/2016.

\section{DAFTAR PUSTAKA}

Astuti, R.P., Iwan, I., (2013), Peningkatan Aktivitas dan Hasil Belajar Melalui PBL Pada Siswa Kelas X SMA, Unnes Journal of Biology Education 42 (2):93-100.

Jihad, A., dan Abdul, H., (2013), Evaluasi Pembelajaran, Penerbit Multi Pressindo, Yogyakarta.

Susilowati, I., Retno, S.I., dan Sri, S., (2013), Pengaruh Pembelajaran Berbasis Proyek Terhadap Hasil Belajar Siswa Materi Sistem Pencernaan Manusia, Unnes Journal of Biology Education 2 (1): 83-90.

Sutirman, (2013), Media dan Model-model Pembelajaran Inovatif, Penerbit Graha IImu, Yogyakarta. 